A N N A L E S

U N I V E R S T A T I S M A R I A E C U R I E-S K L O D O W S K A L U B L I N P O L O N I A

VOL. XVI, 1

SECTIO AI

2016

\title{
CENTRE OF INFORMATION TECHNOLOGIES FOR HUMANITIES AND SOCIAL SCIENCES - A MILESTONE TOWARDS CYBERNATION OF POLISH HUMANITIES
}

\author{
Anna Kurzydłowska ${ }^{1}$, Dorota Stempien ${ }^{1}$ \\ ${ }^{1}$ Department of Informatics and Natural Sciences \\ Cardinal Stefan Wyszynski University in Warsaw
}

KEY WORDS: Centre of Information Technologies, information, technologies

\begin{abstract}
The aim of this paper is to present Center of Information Technologies for Humanities and Social Sciences, which is a cutting-edge initiative taken in order to bring us closer to worldwide achievements in a broadly defined IT infrastructure of humanities and social sciences, digitalization of humanities and the development of virtual medicine. Centre of Information Technologies for Humanities and Social Sciences is a milestone towards cybernation of Polish humanities. It creates an environment for conducting innovative studies with the application of technologies accessible to an IT-oriented society, as well as provides communication with international IT networks to academic units based in Poland.
\end{abstract}

\section{INTRODUCTION}

Cardinal Stefan Wyszynski University, Military Institute of Aviation Medicine and National Information Processing Institute have taken up a challenge to move the world of humanities and social sciences to a new development era. The ambitious project of founding the "Centre of Information Technologies for Humanities and Social Sciences" is a response to modern needs and demands of academic and student circles, as well as individuals looking for an easy, convenient and fast contact with specialists in various areas of medicine, humanities, law, sociology and psychology [1-11].

The centre under construction is a set of modern solutions aimed at providing a continuous and secure access to an advanced information infrastructure, conducting innovative research and securing contact with international scholar ICT networks. The below discussed platforms, built within the Centre project, are - in most cases - a cuttingedge initiatives. Their potential will bring us closer to worldwide achievements in a broadly defined IT infrastructure of humanities and social sciences, digitalization of humanities and the development of virtual medicine [12]. 
The structure of the paper is following. In the next section, we resent project outline, followed by section 3 that contains the review of projects undertaken in the area of Digital Humanities. Section 4 describes Centre of Information Technologies for Humanities and Social Sciences that was built. The last section contains conclusions.

\section{PROJECT OUTLINE}

The pursuit of a cross-border information exchange has been deeply rooted in European culture for ages. The Enlightenment is a good example of such a demand.

The 17th century intellectual elite of scholars, writers, philosophers managed to organize a characteristic prototype of the Internet which came to be called the Republic of Letters [13]. Intellectual elites of the whole Europe and the United States, including Voltaire, Rousseau, Leibnitz, Linnaeus, Franklin, Newton and Diderot, circulated among themselves numerous letters, generating a super-national community of scholars which respected differences in culture and language. Thus, one may deduce, that the phenomenon of social networks, such as Facebook, Twitter or LinkedIn, is not a product of our times, but an improved version of the idea of common coexistence, fostered by our creative ancestors. Modern projects reflect the ways in which the Enlightenment correspondence stretched across national boundaries and build data base by studying and analyzing the development of "Mapping the Republic of Letters" [14].

In the spirit of Plato's philosophy, human pursuit of perfection today has a more pragmatic meaning and it is bound with the necessity of possessing access to knowledge, acquiring new skills and social competencies.

The existent IT enable us to respond to contemporary demand of scholar and business circles for a further e-service development.

The project of "Centre of Information Technologies for Humanities and Social Sciences" is the next step in the process of digital humanities. The digital tools proposed - such as IT Centre for Humanities and Social Sciences, Humanities Digitization Centre, Virtual Diseases of Civilization Platform or integrated, e-communication platforms, as well as competence modules centers e-Law, e-Survey and e-Analysis - will secure access to a technologically advanced infrastructure in order to make it possible to conduct highlevel studies and scientific research, prevent cases of exclusion, facilitate sharing world cultural treasures, co-shape cyberspace and provide free access to knowledge.

According to EU aspirations (Budapest Open Access Initiative, $\mathrm{BOAI}^{1}$ ) societies are supposed to achieve "unprecedented public good" and "accelerate research, enrich education, share the learning of the rich with the poor and the poor with the rich, make

\footnotetext{
${ }^{1}$ Open Access - an initiative going back to 1991 (arXiv.org) and 2000 (PLoS), officially arouses from the conference in Budapest by the Open Society Institute in December 2001. It resulted in a common manifesto Budapest Open Access Initiative signed by 13 representatives of European and American scholar institutions. Similarly, in June 2003, Max Planck Society conference resulted in an informal coalition which called for free of charge access to research
} 
this literature as useful as it can be, and lay the foundation for uniting humanity in a common intellectual conversation and quest for knowledge" [15].

\section{REVIEW OF EXISTING SOURCES}

An excellent example of an already existing cyber-culture in western societies is a network of academics of Cambridge University, who are interested in exploiting digital tools in the development of humanities and social sciences and who perceive digital technology as means of creation new faculties, breaking the traditional barriers of academic research. ${ }^{2}$ University of Oxford hosts a similar community (digital.humanities@oxford) ${ }^{3}$, as well as University College London (UCL Centre for Digital Humanities) ${ }^{4}$, and Universität Leipzig (Digital Humanities Universitat Leipzig) ${ }^{5}$.

The European academic elite had founded numerous programmes, projects, societies, centres and networks co-operating in the area humanities, yet it was the DARIAH-EU initiative (Digital Research Infrastructure for the Arts and Humanities) ${ }^{6}$ that finally consolidated previous undertakings and filled the existing gap. A cooperation forum for members of digital humanities projects has been established in the form of an open platform. DARIAH's aim include technical support, sharing of data, methodology and experience, providing a continuous access to all research data produced or stored by European humanities research projects.

Polish Consortium DARIAH-PL was formed in August 2014. The coordinator of DARIAH-PL is the University of Warsaw while its members include Jagiellonian University, Marie Curie-Sklodowska University, KEN Pedagogical University in Krakow, Silesian University, Academy of Fine Arts in Warsaw, Institute of Literary Research of the Polish Academy of Sciences, Institute of the Polish Language at the Polish Academy of Sciences, Institute of Slavic Studies of the Polish Academy of Sciences, as well as two biggest technology centres responsible for building research infrastructure and digital tools for humanities - Poznan Supercomputing and Networking Centre at the Institute of Bioorganic Chemistry of the Polish Academy of Sciences and Interdisciplinary Centre for Mathematical and Computational Modelling at the Warsaw University, supported by research institutes such as Institute of Computer Science at the Polish Academy of Sciences or Wroclaw University of Technology. The National Library, also a project member, will probably - in cooperation with libraries at the universities - become a competence centre for digitalization and library meta-data standards[16]. Establishing the Consortium formed a natural space for sharing ideas on a new paradigm - digital humanities, creating new tools and developing new, common research projects. The newly established organization's objective is to promote nationwide and European research cooperation in digital humanities, sharing experience and competencies among consortia,

\footnotetext{
${ }^{2}$ http://www.cam.ac.uk/

${ }^{3}$ http://digital.humanities.ox.ac.uk/

${ }^{4}$ https://www.ucl.ac.uk/dh

${ }^{5}$ http://www.dh.uni-leipzig.de/wo/

${ }^{6} \mathrm{https}: / / \mathrm{www}$. dariah.eu
} 
as well as cooperation with other institutions, research networks, advanced technology centres in Poland and Europe.

From a global point of view, one must mention ADHO (Alliance of Digital Humanities Organizations) which promotes and supports digital research and teaching in all fields and disciplines of the humanities. It acts as a community-based advisory force and in subvention of research, publications and trainings. At present $\mathrm{ADHO}^{7}$ members include: European Association for Digital Humanities (EADH), Association for Computers and the Humanities (ACH), Canadian Society for Digital Humanities (CSDH), centerNet, Australasian Association for Digital Humanities (aaDH), Japanese Association for Digital Humanities (JADH).

CLARIN $^{8}$ constitutes another interesting example of undertakings which unites and activates scholar and research community. It is an acronym for Common Language Resources and Technology Infrastructure established by European scholars working on digital archives and processing of digital language data in the humanities and social studies. Its objectives are to provide research infrastructure for scholars, to build a cybernetwork for storing data and sharing archives, to disseminate materials and to use them in various research contexts. CLARIN's members are: Austria, Bulgaria, the Czech Republic, Denmark, Estonia, Germany, Greece, Lithuania, the Netherlands, Norway (observer), Sweden, and Poland (CLARIN-PL) ${ }^{9}$. Wroclaw University of Technology is the leader of CLARIN-PL consortium - a Polish unit of a pan-European research infrastructure including digital text archives and tools for their automatic analysis. CLARIN network provides software which enables the use of the previously developed digital archives and corpora. New resources are created, stored and shared. It is also possible to work on raw texts published on the Internet in the form of press releases, articles, blogs and documents. Unlike commercial internet search engines, which work best with a small set of key words, CLARIN's tools may "understand" whole analysed texts and therefore, they are able to find information related directly to the user's interest without having to try various combinations of terms. It is particularly useful when one looks for connections among chosen elements (persons, places, institutions, enterprises, etc.) within a huge set of source texts.

CLARIN's tools are extremely useful in automatic text summarization, search for entity names, morphological and syntactic analysis. Such data processing supports scholar circles in analyses of political, social or advertising discourse. Besides, CLARIN's software responds to users' needs and a user-friendly interface does not require advanced knowledge of information technology. Due to the implemented standards, the tools for Polish language (CLARIN-PL) are fully compatible with tools provided by other European CLARIN centres. It ensures the flexibility in combining individual tools into single- or multilingual processing systems to maximize the amount of information obtained from the texts.

\footnotetext{
${ }^{7}$ adho.org

${ }^{8}$ http://www.clarin.eu

${ }^{9} \mathrm{http} / / /$ clarin-pl.eu
} 


\section{CENTRE OF INFORMATION TECHNOLOGIES FOR HUMANITIES AND SOCIAL SCIENCES PROJECT}

Presented in this paper project "The Centre of Information Technologies for Humanities and Social Sciences" provides the scholar environment in Poland with another tool for cyber-development via an integrated electronic platform for communication consisting of two analytical modules:

- e-Law,

- e-Survey \& e-Analysis,

as well as integrated platforms of communication:

- e-Connector,

- e-Conference,

- Virtual Diseases of Civilization Platform.

\subsection{E-Law Module}

This module is aimed at creating a set of tools (software) to search for information across legal documents and support legislative work. It will enable building indexes of documents, context searching and automatic processing of legislative documents, searching and storing of accessible legal acts, specialized translations of legal acts and documents.

This module partially refers to the already existing bases such as

- Beck Online - a German data base containing statutory texts, commentaries, manuals and several law journals including archive data ${ }^{10}$,

- Westlaw International, a global electronic library of legal acts covering legal science, legislative, particular cases and processes in the EU and Englishspeaking countries in the world. It includes contents of over 1000 law journals or scientific works, reviews, address data-bases. Current information published in leading world journals and weeklies, data on intellectual property, patents and trading marks, copyrights may also be found at Westlaw International site. ${ }^{11}$

- EUR-Lex is another form of electronic Official Journal containing EU legislative acts, EU law and other documents published in 24 languages ${ }^{12}$.

It is worth mentioning that currently, in Poland, the following systems/databases are being constructed:

- Database being built by the Polish Law Bibliography containing, apart from law texts (including theory and history of state and law, international law, public law, penal law) texts on world history, political doctrines, international relations,

\footnotetext{
${ }^{10} \mathrm{http}: / /$ beck-online.beck.de

${ }^{11} \mathrm{http} / / /$ westlawinternational.com

12 http://eur-lex.europa.eu
} 
auxiliary penal law sciences (criminology, forensic studies, judicial psychiatry, psychology, medicine) $)^{13}$ chosen on the basis of its relations Polish Law Bibliography.

- LEX Law Information System - a constantly updated base of documents which enables searching across an expanded data via a dictionary, key words and filters and makes it possible to personalize the software by marking documents as favourite or commenting them ${ }^{14}$.

- ISAP Internet System of Legal Acts containing bibliography and law texts published officially in Journal of Law, Monitor Polski (official gazette of the Polish government) ${ }^{15}$.

- Legalis System of Legal Information storing full texts of legal acts since 1918, jurisdiction of European and Polish courts of Law since 1925, including the unpublished verdicts of Supreme Courts, samples of documents, agreements (additionally annotated), database containing addresses of public bodies, data on economic indexes, news and timetable informing about changes in law, Polish Law Bibliography since 1970, commentary modules linked to data base with acts of law, monographies and journals by C.H. Beck, integrated English, German and Russian dictionaries, translations of legal acts, writing samples of agreements and other documents ${ }^{16}$.

We produce millions of texts nowadays. Their exploration is time-consuming and difficult. Therefore, application of automatic methods of analysis and access to innovative techniques of storing and processing data becomes so important. Text-mining is a discipline enabling to find knowledge hidden in the texts and this technique will be used in the above mentioned e-Law Module.

\subsection{E-Survey And E-Analysis Modules}

E-Survey and e-Analysis are other platforms, collecting surveys and analysing data, which have been announced to be built. An automatic tool for creating/building surveys is to be developed. It is meant to allow the user to create forms of a survey and - with the use of controlling tools - formulate closed questions, build dedicated questionnaires. A defined pattern will make it possible to send the survey to a number of e-mail addresses, collect responses.

The Internet offers similar solutions - numerous services provide extensive range of tools allowing to create and make an online survey, invite respondents and collect

\footnotetext{
${ }^{13}$ http://www.ipn.pan.pl

${ }^{14} \mathrm{http} / / / \mathrm{www} \cdot$ produkty.lex.pl

${ }^{15} \mathrm{http} / / /$ isap.sejm.gov.pl

${ }^{16}$ http://pka.bj.uj.edu.pl
} 
questionnaires, as for example: ebadania.pl ${ }^{17}$, interankiety ${ }^{18}$, survio $^{19}$, webankieta ${ }^{20}$. Yet, e-Survey and e-Analysis will bring some freshness by allowing various kinds of tabular report to be created (simple and complex ones), adding statistics for each slot and introducing summing up. An interesting solution is a possibility to create a presentation of results adjusted to users' needs - with ready-made or user-built forms - and to use a set of chart-types presenting clearly the interdependence of data and analysis.

\subsection{E-Connector And E-Conference Platform}

E-Connector is a tool analogical to the already existing social networks like Facebook, Google+. Yet, the system to be constructed, will be dedicated to scholar and research circles, easys to operate and each academic or doctoral student will have a possibility to create his/her profile /event site.

E-Conference will enable to organize online conferences - scholar, press, seminar or symposia.

\subsection{Virtual Diseases Of Civilization Platform}

Finally, the project being discussed, envisages the building of the Virtual Diseases of Civilization Platform. It assumes the establishment of virtual health promotion stations, educational and information portal, or global information system allowing visualisation of medical data concerning the so-called diseases of civilization.

This is a cutting-edge undertaking as so far no such an advanced and complex Virtual Disease of Civilization Centre has been established in Poland.

The project is aimed at providing patients with the possibility to contact, easily and conveniently, specialists in various disciplines, and serve as a remedy to the complaints concerning inadequate access and quality of medical services.

Currently, digital technology in medicine can be seen in several projects. Wielkopolska Centre of Telemedicine Project is building its infrastructure aimed at providing numerous telemedical services. These services will enable specialists in clinical wards at the Medical Univeristy of Poznan to share knowledge and experience with other colleagues employed in the regional health service. The project's aim is to provide telemedical services to Health Service in Wielkopolska": medical teleconsultations, teleeducational medicine, supporting clinical decisions, reporting to specialist supervisor [17].

An example of individual, yet worth noticing initiative, has been presented by graduate students of PWSZ in Nysa who opened a virtual diet guidance centre.

\footnotetext{
${ }^{17}$ http://www.ebadania.pl

${ }^{18} \mathrm{http}: / / \mathrm{www}$.interankiety.pl

${ }^{19} \mathrm{http} / / / \mathrm{www}$. survio.com/pl

${ }^{20} \mathrm{http}: / /$ www.webankieta.pl
} 
Another cutting-edge application Skin Check makes it possible to analyse the state of skin lesions with the use of new technologies. In an easy and fast way, a user who possesses an adequate operating system, had installed the application, created profile and sent photographs of lesions, taken by a digital camera, will receive a preliminary analysis of skin changes. Shortly after, automatically, after all data had been collected, a diagnosis including suggestions concerning further steps will be sent to his/her account.

All such initiatives are aimed at promoting the development of telemedicine, ehealth, disease prevention, social education in order to avoid risk factors causing civilization diseases. Virtual Diseases of Civilization Centre responds, therefore, to one of the biggest health problems afflicting highly developed societies and quickly developing countries, including Poland.

\section{SUMARY}

To sum up, Centre of Information Technologies for Humanities and Social Sciences is a milestone towards cybernation of Polish humanities.

The objectives of the project ensure the creation, development and management of a modern IT infrastructure for the academic community in Poland, in the fields of humanities and social sciences.

They guarantee a possibility to conduct innovative studies with the application of technologies accessible to an IT-oriented society, as well as provide communication with international IT networks to academic units based in Poland

\section{LITERATURE}

1. A Companion to Digital Humanities. Edited by S. Schreibman, R. Siemens, J. Unsworth. Oxford: Blackwell, 2004.

2. A Companion to Digital Literary Studies. Edited by R. Siemens, S. Schreibman. Oxford: Blackwell, 2008.

3. Debates in the Digital Humanities. Red. Matthew K. Golda. Minnesota: University of Minnesota Press, 2012.

4. Digitalizacja piśmiennictwa. Oprac. i red. Dariusz Paradowski. Warszawa: Biblioteka Narodowa, 2010.

5. E-polonistyka. Red. A. Dziak, S. J. Żurek. Lublin: Wydawnictwo KUL, 2009.

6. Paradoksy Internetu. Konteksty społeczno-kulturowe. Red. M. Szpunar. Toruń: Wydawnictwo Adam Marszałek, 2011.

7. Szpunar M. Nowe-stare medium. Internet między tworzeniem nowych modeli komunikacyjnych a reprodukowaniem schematów komunikowania masowego. Warszawa: IFiS PAN, 2012.

8. Szpunar M. Internet $w$ procesie realizacji badań. Toruń: Wydawnictwo Adam Marszałek, 2010.

9. Szpunar M. W stronę nowych mediów. Toruń: Wydawnictwo Adam Marszałek, 2010. 
10. Trembowiecki A. Digitalizacja zbiorów bibliotecznych: teoria $i$ praktyka. Warszawa: Centrum Edukacji Bibliotekarskiej, Informacyjnej i Dokumentacyjnej im. Heleny Radlińskiej w Warszawie, 2006.

11. Zwrot cyfrowy $w$ humanistyce. Red. Andrzej Radomski, Radosław Bomba. E-naukowiec. Lublin, 2013.

12. Nacher A.: Poza cyfrowość w zwrocie cyfrowym - od humanistyki cyfrowej do spekulatywnej komutacji. [W:] Zwrot cyfrowy w humanistyce. Internet / nowe media / kultura 2.0. Red. A. Radomski, R. Bomba. Wydaw. E-naukowiec, Lublin 2013

13. Wieczorek-Tomaszewska M.: Cyfrowa humanistyka jako metaforyczna wspótczesna Republika Listów. Kraków: Katedra Technologii i Mediów Edukacyjnych (współpraca) Uniwersytet Pedagogiczny, http:www.ktime.up.krakow.pl/symp2013/referaty_2013_10/wieczorek.pd, 2013

14. Winterer C.: Where is America in the Rrepublic of Letters?”, Modern Intellectal History 9, 3 (Nov, 2012): p. 597-623

15. Velterop J.JM.: Open Access Publishing and Scholarly Societies Guide, Open Society Institute, NY, July 2005

16. Kuźmina D.: W drodze do DARIAH, pismo Uniwersytetu Warszawskiego, 3 (69), October 2014

17. Brzeziński J., Kosiedowski, M., Mazurek C., Słowiński K., Słowiński R., Stroiński M., Węglarz J.: Towards telemedical centers - digitization of inter-professional communiaction in healthcare. [In:] M.M., Cruz-Cunha, M. Miranda (eds.), Handbook of Research on ICTs and Management Systems for Improving Efficiency in Healthcare and Social Services, IGI Global 2013, p. 805-829

18. ADHO - The Alliance of Digital Humanities Organizations, https://adho.org

19. CLARIN-EU, CLARIN-PL - Common Language Resources \& Technology Infrastructure, http://www.clarin.eu, http://clarin-pl.eu

20. DARIAH-EU, DARIAH- PL - The Digital Research Infrastructure for the Arts and Humanities, https://www.dariah.eu, https://dhlab.uw.edu.pl/konferencja-dariah-pl

21. Mapping the Republic of Letters is a project Humanities Design at CESTA, Stanford University, http://republicofletters.stanford.edu/index.html

22. http://www.cam.ac.uk

23. http://digital.humanities.ox.ac.uk

24. http://www.budapestopenaccessinitiative.org

25. https://www.ucl.ac.uk/dh

26. http://www.dh.uni-leipzig.de/wo

27. http://beck-online.beck.de

28. http://westlawinternational.com

29. http://eur-lex.europa.eu 
Pobrane z czasopisma Annales AI- Informatica http://ai.annales.umcs.pl

Data: 26/04/2023 05:50:27

30. http://www.ipn.pan.pl

31. http://www.produkty.lex.pl

32. http://isap.sejm.gov.pl

33. http://pka.bj.uj.edu.pl

34. http://www.ebadania.pl

35. http://www.interankiety.pl

36. http://www.survio.com/pl

37. http://www.webankieta.pl

38. http://telemedycyna.wlkp.pl

39. http://super-linia.com./

40. http://www.zdrowepomysly.pl

41. http://dl.psnc.pl/2012/09/05/konferencja-digital-humanities-2012/

42. http://www.cyberhumanistyka.ukw.edu.pl/ 